\title{
Evaluasi Pertumbuhan Ayam Kamaras Jantan dengan Pemberian Tepung Ampas Tahu + Tepung Kulit Telur + Feed Supplement
}

\author{
(Evaluation of Male Kamaras Chicken Growth Fed Tofu Waste \\ Meal + Egg Shell Meal + Feed Supplement)
}

\author{
M. Aman Yaman, Zulfan, Iza Zulfiza \\ Program Studi Peternakan, Fakultas Pertanian, Universitas Syiah Kuala
}

\begin{abstract}
Abstrak: Tujuan penelitian ini adalah untuk mengetahui pertumbuhan ayam kamaras jantan dengan pemberian ransum komersil yang sebagian disubstitusi dengan tepung ampas tahu + tepung kulit telur + feed supplement. Penelitian dilakukan di Laboratorium Lapangan Peternakan (LLP), Fakultas Pertanian, Universitas Syiah Kuala, Banda Aceh tanggal 7 Januari-16 Maret 2016. Penelitian menggunakan 64 ekor DOC (Day Old Chick) ayam kamaras. Perlakuan yang dicobakan adalah ransum komersil broiler 512 Bravo yang disubtitusi dengan tepung ampas tahu + tepung kulit telur + feed supplement sebanyak $0 \%\left(\mathrm{P}_{1}\right), 5 \%+1 \%+1 \%\left(\mathrm{P}_{2}\right), 10 \%+2 \%+1 \%\left(\mathrm{P}_{3}\right)$, dan $15 \%+3 \%+1 \%\left(\mathrm{P}_{4}\right)$. Parameter yang diamati adalah berat badan akhir, pertambahan berat badan, konsumsi ransum, konversi ransum, dan mortalitas. Hasil penelitian memperlihatkan bahwa meskipun secara statistik perbedaannya tidak nyata $(\mathrm{P}>0,05)$, penggunaan tepung ampas tahu + tepung kulit telur + feed supplement cenderung menaikkan berat badan dan pertambahan berat badan, konsumsi ransum, dan memperbaiki angka konversi ransum ayam kamaras.
\end{abstract}

Kata Kunci : ampas tahu, kulit telur, feed supplement, ayam kamaras, pertumbuhan

\begin{abstract}
The purpose of this study was to determine the growth of male kamaras chickens fed a broiler commercial ration partially substituted with tofu waste meal + egg shell meal + feed supplement. The research was conducted at the Field Lab, Faculty of Agriculture, Syiah Kuala University, Banda Aceh on January 7 until March 16, 2016. The study used 64 DOC (Day Old Chick) of male kamaras. The treatments were using broiler commercial ration partially substituted with tofu waste meal + egg shell meal + supplement with different level. Parameters measured were final body weight (FBW), average body weight gain (BWG), feed intake, and feed conversion. The results of study showed that although statistically no significant effects were detected $(\mathrm{P}>0.05)$ using tofu waste meal up to $15 \%$ + eggshell meal $3 \%$ + feed supplement $1 \%$ as a partial substitution of broiler commercial ration tended to increase final body weight, average body weight gain (BWG), and feed intake and repair feed conversion of male kamaras chickens.
\end{abstract}

Keywords: tofu, egg shell, supplement, chicken kamaras, growth

\section{PENDAHULUAN}

Ayam kamaras merupakan hasil persilangan tiga bangsa ayam, yaitu ayam ras jantan, ayam kampung betina, dan ayam arab betina (Yaman et al., 2011). Maksud dan tujuan persilangan bangsa-bangsa ayam ini adalah untuk memperbaiki kualitas dan produktivitas ayam kampung. Telur ayam arab diketahui memiliki kemiripan dengan telur ayam kampung (Natalia et al., 2005), sedangkan produksi telurnya lebih tinggi dibandingkan dengan produksi telur ayam kampung (Triharyanto, 2001; Pambudhi, 2003).

Perkawinan ayam ras jantan dengan induk betina ayam kampung akan menghasilkan ayam silangan dengan produksi telur yang lebih tinggi daripada produksi telur ayam kampung. Akan tetapi, penampilan telur dari ayam hasil silangan ini tidak sebaik dibandingkan dengan penampilan telur ayam kampung. Ayam jantan hasil silangan tersebut dikawinkan kembali dengan ayam arab betina sehingga dihasilkan ayam silangan baru yang disebut ayam kamaras. 
Kualitas daging ayam kamaras diperkirakan lebih unggul dibandingkan dengan daging ayam arab. Hal ini disebabkan adanya kombinasi genetik antara ketiga bangsa ayam tersebut; ayam kampung, ayam arab, dan ayam ras. Berdasarkan kenyataan ini, ayam kamaras pedaging memiliki potensi untuk dikembangkan. Berdasarkan Sulandari et al. (2007), ayam arab dapat disilangkan dengan ayam lokal lain untuk memperoleh produksi telur yang lebih tinggi dengan kualitas daging yang lebih baik

Salah satu kendala dalam mengusahakan ayam kamaras pedaging adalah biaya ransum. Penggunaan seratus persen ransum komersil broiler dipandang kurang ekonomis, sehingga perlu disubstitusi dengan bahan pakan lain yang harganya lebih murah dan ketersediaannya berlimpah. Bahan pakan yang dimaksud, antara lain, adalah ampas tahu dan kulit telur.

Ampas tahu merupakan hasil limbah padat yang telah diambil sarinya atau patinya atau limbah industri pangan yang telah diambil sarinya melalui proses pengolahan secara basah yang diperoleh dari proses pembuatan tahu dari kedelai. Penggunaan ampas tahu sebagai pakan ternak telah umum dilakukan oleh masyakarat karena ampas tahu memiliki kandungan protein yang cukup tinggi (Prabowo et al., 1983) dan kualitas proteinnya baik untuk ternak (Prabowo et al.; Masturi et al. (1992). Ampas tahu yang telah diolah (fermentasi dengan menggunakan ragi tempe) dapat digunakan hingga $12 \%$ dalam ransum ayam pedaging tanpa mengganggu pertumbuhan (Nur et al., 1997).

Cangkang telur merupakan bagian terluar dari telur yang berfungsi melindungi semua bagian telur dari kerusakan, baik secara fisik, kimia, maupun mikrobiologis. Cangkang telur tidak dikonsumsi oleh manusia, sehingga merupakan limbah yang terbuang. Cangkang kulit telur saat ini pun telah banyak digunakan sebagai sumber kalsium (Butcher dan Miles, 1990) untuk campuran di dalam ransum komersil.

Penggunaan bahan-bahan pakan alternatif terutama yang berasal dari limbah dan hasil sampingan bisanya menurunkan kualitas ransum. Hal ini dikarenakan umumnya bahan pakan hasil sampingan seperti ampas tahu mengandung serat kasar yang tinggi. Permasalahan ini dapat diatasi dengan cara penambahan feed supplement. Feed Supplement adalah bahan makanan yang berupa campuran preparat enzim, vitamin, mineral, dan antibiotik guna melengkapi ransum yang kemungkinan kekurangan (defiensi) zat-zat makanan tersebut (Anggorodi, 1985).

Permasalahannya adalah apakah dengan menggunakan ampas tahu dan kulit telur sebagai substitusi sebagian ransum komersil ditambah dengan feed supplement mempengaruhi pertumbuhan ayam kamaras. Hal ini dikarenakan pertumbuhan sangat ditentukan oleh ransum yang diberikan. Tujuan penelitian ini adalah untuk mengetahui pertumbuhan ayam kamaras jantan dengan pemberian ransum komersil yang sebagian disubstitusi dengan tepung ampas tahu + tepung kulit telur + feed supplement .

\section{MATERI DAN METODE}

\section{Tempat dan Waktu}

Penelitian ini dilakukan di Laboratorium Lapangan Peternakan (LLP), Program Studi Peternakan, Fakultas Pertanian, Universitas Syiah Kuala, Banda Aceh tanggal 7 Januari sampai dengan 16 Maret 2016.

\section{Materi, Bahan, dan Alat Penelitian}

Penelitian ini menggunakan 64 ekor DOC ayam kamaras. Bahan yang digunakan dalam penelitian ini terdiri dari ransum komersil (R511 Bravo dan R512 Bravo), ampas tahu, kulit telur ayam, feed supplement (top mix), vaksin ND, vaksin gumboro, desinfektan, 
vitachick, vitastress, koran bekas, litter, dan kapur. Peralatan yang digunakan meliputi kandang individual, tempat pakan, tempat minum, bola lampu pemanas, bola lampu penerang, timbangan digital, dandang, kompor, alat peniris, disc mill, dan peralatan penunjang kandang.

\section{Ransum Perlakuan}

Penelitian ini menggunakan ransum dasar berupa ransum komersil broiler R511 dan R512 (Produksi PT. Charoen Phokphand, Medan). Ransum R512 disubstitusi dengan tepung ampas tahu + tepung kulit telur + feed supplement. Susunan ransum perlakuan adalah sebagai berikut :

$\mathrm{P}_{1} \quad=$ Ransum komersil R512 100\% (kontrol)

$\mathrm{P}_{2}=$ Ransum komersil R51293\% + Tepung Ampas Tahu 5\% + Tepung Kulit Telur $1 \%+$ Feed Supplement $1 \%$

$\mathrm{P}_{3}=$ Ransum komersil R512 87\% + Tepung Ampas Tahu 10\% + Tepung Kulit Telur $2 \%+$ Feed Supplement $1 \%$.

$\mathrm{P}_{4}=$ Ransum komersil R512 81\% + Tepung Ampas Tahu 15\% + Tepung Kulit Telur $3 \%+$ Feed Supplement $1 \%$.

Tabel 1. Susunan dan Kandungan Zat Gizi Ransum Penelitian

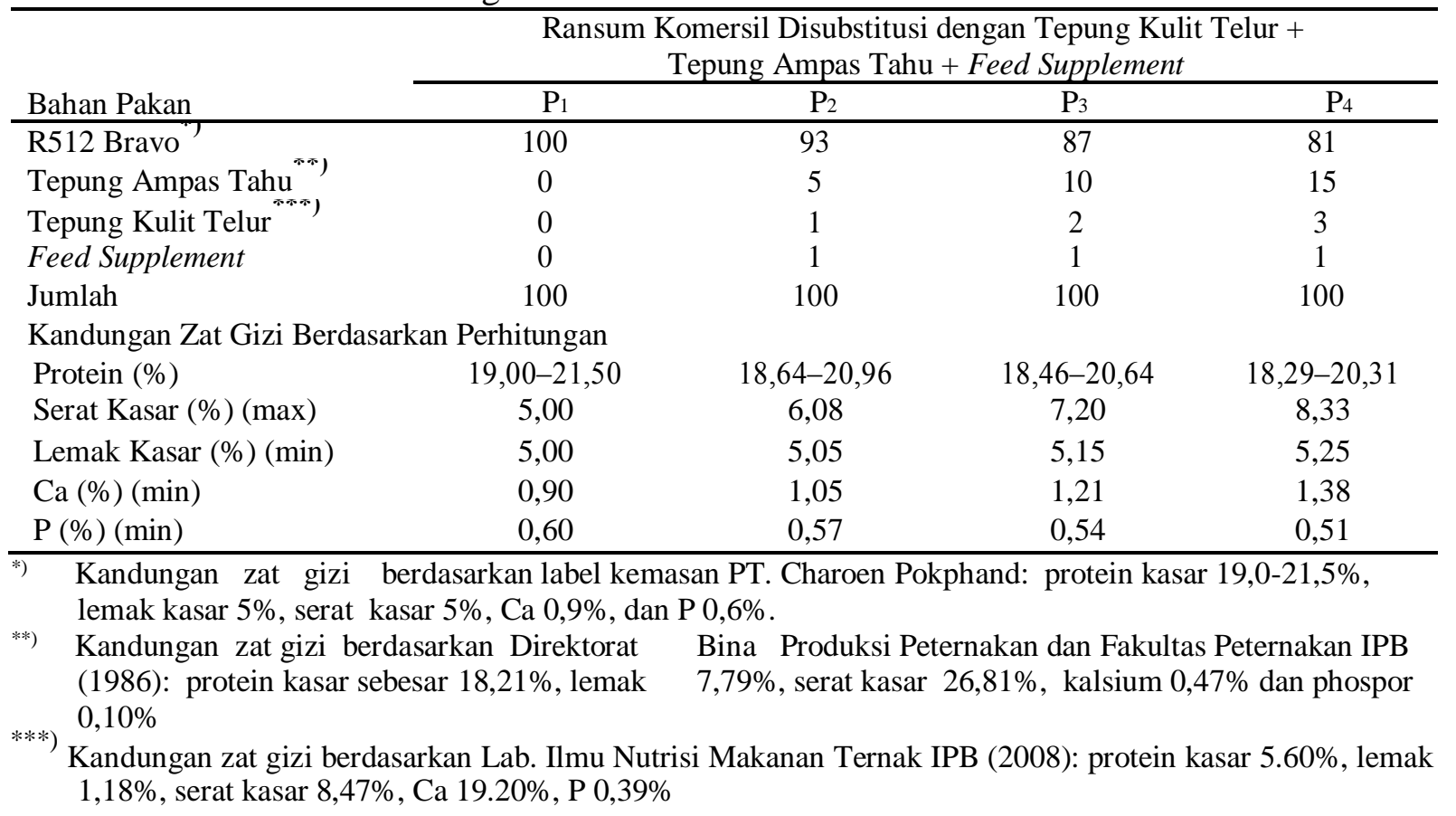

\section{Rancangan Penelitian}

Rancangan penelitian yang digunakan adalah Rancangan Acak Lengkap (completely randomized design), terdiri dari 4 perlakuan dan 4 ulangan. Setiap ulangan merupakan unit percobaan yang masing-masing terdiri dari empat ekor ayam sehingga total ayam 64 ekor. Perlakuan yang diberikan adalah penggunaan ransum komersil R512 Bravo yang sebagian disubstitusi dengan tepung ampas tahu, tepung kulit telur, dan feed supplement dengan taraf yang berbeda. Bagan penelitian yang dilakukan disajikan pada Tabel 4. 
Model matematika penelitian yang akan digunakan menurut Steel dan Torrie (1993):

$$
\mathrm{Y}_{\mathrm{ij}}=\mu+\tau_{\mathrm{i}}+\varepsilon_{\mathrm{ij}}
$$

Keterangan:

$Y_{i j} \quad$ : Nilai pengamatan

$\mu \quad$ : Nilai tengah umum

$\tau_{\mathrm{i}} \quad$ : Pengaruh perlakuan ke- $i$

$\varepsilon_{i j} \quad$ : Pengaruh galat perlakuan ke-i, ulangan ke- $j$

\section{Pembuatan Tepung Ampas Tahu dan Kulit Telur}

Pembuatan tepung ampas tahu dilakukan dengan tahapan sebagai berikut: (1) ampas tahu dikumpulkan dari pabrik pembuatan tahu, (2) ditiriskan, (3) dijemur sampai kering di bawah sinar matahari, dan (4) digiling dengan menggunakan disc mill. Sedangkan pembuatan tepung kulit telur dilakukan dengan tahapan sebagai berikut: (1) kulit telur dikumpulkan dari pedagang martabak, (2) dicuci, (3) direbus, (4) ditiriskan, (5) dijemur sampai kering di bawah sinar matahari, dan (6) digiling dengan menggunakan disc mill.

\section{Pelaksanaan Penelitian}

Penelitian ini dilakukan dalam tiga tahap, yaitu:

a. Tahap Persiapan: Tahap persiapan meliputi persiapan kandang dan ransum. Persiapan kandang terdiri dari sanitasi kandang (dalam kandang dan luar kandang), pencucian kandang, penyemprotan kandang luar dan dalam, desinfektan, persiapan tempat pakan dan tempat minum, dan pembuatan unit-unit percobaan. Masing-masing unit percobaan diberi kode perlakuan secara acak dan dilengkapi dengan tempat pakan dan tempat minum. Persiapan ransum terdiri dari pembuatan tepung ampas tahu dan tepung kulit telur serta pencampuran bahan pakan.

b. Tahap Pemeliharaan: Tahap ini terdiri dari masa adaptasi dan masa pemberian perlakuan. Masa adaptasi dilakukan selama satu minggu dimana anak ayam dipelihara di dalam brooder dan diberikan seratus persen ransum komersil broiler 511 Bravo untuk semua perlakuan, konsumsi ransum tetap diperhitungkan. Setelah satu minggu, anak ayam ditempatkan secara acak ke dalam unit-unit percobaan dan diberikan ransum sesuai perlakuan masing-masing sampai umur sepuluh minggu. Pemberian ransum dilakukan dua kali sehari yaitu pada pukul 07.00 dan 17.00 WIB. Ransum diberikan ad libitum dan dihitung setiap seminggu sekali. Air minum juga diberikan ad libitum.

c. Tahap Pengambilan dan Analisa Data : Tahap pengambilan data untuk bobot badan dilakukan setiap minggu dari minggu pertama hingga minggu terakhir. Semua ayam dari setiap unit percobaan ditimbang untuk mengetahui berat badan dan pertambahan berat badan tiap-tiap minggu. Pengambilan data untuk konsumsi ransum sisa ditimbang setiap minggu dengan menghitung jumlah ransum yang diberikan, dikurangi ransum yang tersisa untuk mengetahui konsumsi ransum mingguannya. Perhitungan konversi ransum diperoleh dari data konsumsi ransum dan pertambahan berat badan.

\section{Parameter Penelitian}

Parameter yang diamati dalam penelitian adalah performan ayam kamaras selama pemeliharaan tujuh puluh hari yang meliputi berat badan, pertambahan berat badan, konsumsi ransum, konversi ransum, dan mortalitas. 


\section{Analisis Data}

Data hasil penelitian ini dianalisis menggunakan Analysis of Variance (ANOVA). Jika pada analisis ANOVA didapat hasil yang berbeda nyata maka dilanjutkan dengan Uji Jarak Berganda Duncan (Steel dan Torrie 1993).

\section{HASIL DAN PEMBAHASAN}

\section{Berat Badan dan Pertambahan Berat Badan}

Berat badan akhir ayam kamaras dalam penelitian ini dihitung pada akhir minggu ke -8 , 9, dan 10. Rataan pertambahan berat badan per minggu (PBB) dihitung berdasarkan rata-rata PBB per minggu ayam kamaras selama pemeliharaan 8, 9, dan 10 minggu. Berat badan akhir dan rataan pertambahan berat badan per minggu ayam kamaras dengan pemberian ransum komersil broiler 512 Bravo yang disubstitusi dengan tepung ampas tahu + tepung kulit telur + feed supplement selama pemeliharaan 8, 9, dan 10 minggu diperlihatkan pada Tabel 2.

Tabel 2. Berat Badan Akhir dan Rataan Pertambahan Berat Badan per minggu Ayam Kamaras yang diberi Ransum Komersil yang Disubstitusi dengan Tepung Ampas Tahu dan Tepung Kulit Telur + Feed Supplement

\begin{tabular}{|c|c|c|c|c|c|}
\hline \multirow{2}{*}{\multicolumn{2}{|c|}{$\begin{array}{l}\text { Parameter } \\
(\text { minggu })\end{array}$}} & \multicolumn{4}{|c|}{ Perlakuan } \\
\hline & & P1 & $\mathrm{P} 2$ & P3 & P4 \\
\hline \multicolumn{6}{|c|}{ Berat badan akhir (final body weight) (g/ekor) } \\
\hline & Umur 8 minggu & $671,88 \pm 42,44$ & $694,63 \pm 34,25$ & $672,88 \pm 87,75$ & $689,31 \pm 65,35$ \\
\hline & Umur 9 minggu & $727,13 \pm 42,29$ & $779,00 \pm 42,85$ & $750,25 \pm 110,06$ & $776,56 \pm 80,36$ \\
\hline & Umur 10 minggu & $822,13 \pm 31,25$ & $848,13 \pm 46,16$ & $830,25 \pm 108,70$ & $857,50 \pm 86,72$ \\
\hline \multicolumn{6}{|c|}{ Rataan pertambahan berat badan per minggu (average body weight gain) (g/ekor/minggu) } \\
\hline & $0-8$ minggu & $80,46 \pm 5,31$ & $83,30 \pm 4,28$ & $80,58 \pm 10,97$ & $82,64 \pm 8,17$ \\
\hline & 0-9 minggu & $77,66 \pm 4,70$ & $83,42 \pm 4,76$ & $80,23 \pm 12,23$ & $83,15 \pm 8,93$ \\
\hline & $0-10$ minggu & $79,39 \pm 3,12$ & $81,69 \pm 4,22$ & $80,20 \pm 10,87$ & $82,93 \pm 8,67$ \\
\hline \multicolumn{6}{|c|}{$\mathrm{P}_{1}=$ Ransum Komersil R512 100\% (kontrol) } \\
\hline $\begin{array}{l}\mathrm{P}_{2} \\
\mathrm{P}_{3}\end{array}$ & $\begin{array}{l}=\text { Ransum Komersil R512 } \\
=\text { Ransum Komersil R512 }\end{array}$ & $\begin{array}{l}93 \%+\text { Tepung Ampas Tahu } 5 \% \\
87 \% \text { + Tepung Ampas Tahu } 10\end{array}$ & ung Kulit Telur 1\% & $\begin{array}{l}\text { eed Supplement } 1 \% \\
\text { Feed Supplement } 1 \%\end{array}$ & \\
\hline $\mathrm{P}_{4}$ & $=$ Ransum Komersil R512 & $81 \%+$ Tepunga Ampas Tahu & & & \\
\hline
\end{tabular}

Hasil sidik ragam memperlihatkan bahwa pemberian ransum komersil broiler 512 Bravo yang disubstitusi dengan tepung ampas tahu + tepung kulit telur + feed supplement tidak berpengaruh nyata $(\mathrm{P}>0,05)$ terhadap berat badan akhir ayam kamaras (akhir minggu ke-8, 9, dan 10) dan rataan pertambahan berat badan (PBB) per minggu selama 8, 9, dan 10 pemeliharaan. Rataan berat badan dan PBB ayam kamaras per minggu dari semua perlakuan tidak jauh berbeda. Namun demikian, ada kecenderungan ayam-ayam yang diberi ransum yang mengandung tepung ampas tahu + tepung kulit telur + feed supplement $\left(\mathrm{P}_{2}-\mathrm{P}_{4}\right)$ memiliki berat badan dan $\mathrm{PBB}$ yang lebih tinggi dibandingkan dengan ayam-ayam yang mendapatkan ransum komersil seratus persen $\left(\mathrm{P}_{1}\right)$. Hal ini memperlihatkan bahwa tepung ampas tahu dan tepung kulit telur ditambah feed supplement dapat digunakan untuk mensubstitusi ransum komersil broiler 512 Bravo sampai 19\% tanpa menurunkan bobot badan badan akhir ayam kamaras, bahkan bobot badannya lebih tinggi. 


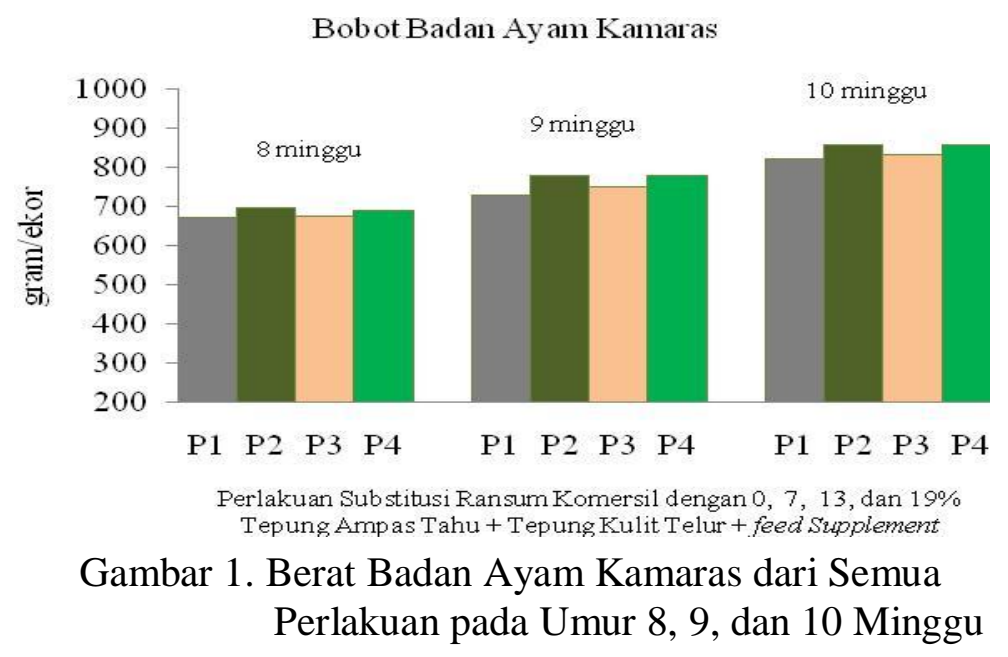

Kenaikan berat badan ayam-ayam kamaras yang mendapatkan tepung ampas tahu + tepung kulit telur + feed supplement diduga karena adanya tambahan unsur-unsur nutrisi yang berasal dari tepung ampas tahu + tepung kulit telur + feed supplement yang dapat dimanfaatkan secara efisien oleh ayam kamaras. Berdasarkan Pulungan dan Rangkuti (1984), limbah tahu masih mengandung protein yang cukup tinggi tetapi rendah $\mathrm{Ca}$. Kandungan mineral $\mathrm{Ca}$ dalam ransum substitusi dapat dinaikkan kembali dengan adanya penambahan tepung kulit telur yang mengandung $\mathrm{CaCO}_{3}$ yang tinggi (Butcher dan Miles, 1990). Kalsium digunakan oleh ayam untuk pembentukan tulang dan jaringan lainnya di dalam tubuh (Anggorodi, 1985), sedangkan unsur-unsur gizi lainnya dapat dilengkapi dari feed supplement.

Berat badan ayam kamaras jauh lebih rendah bila dibandingkan dengan berat badan ayam broiler pada umur yang sama. Pada umur 5-6 minggu, ayam broiler dapat menghasilkan bobot badan 1,5-1,9 kg/ekor (Amrullah, 2006), jauh lebih tinggi daripada ayam kamaras. Ini dikarenakan perbedaan tipe ayam, ayam broiler merupakan tipe pedaging yang memiliki keunggulan genetik dalam pertumbuhan, sedangkan ayam kamaras adalah tipe

petelur. Dalam penelitian ini, ransum yang digunakan adalah ransum komersil ayam broiler dengan kandungan nutrisi disesuaikan dengan kebutuhan zat gizi ayam broiler. Pemberian seluruhnya ransum komersil broiler pada ayam kamaras tidak akan mampu mencapai berat badannya seperti berat badan ayam broiler dikarenakan perbedaan kebutuhan zat gizi dan genetiknya. Dengan demikian, ayam kamaras tidak memerlukan jumlah zat gizi seperti yang dibutuhkan ayam broiler. Atas dasar inilah digunakan bahan-bahan pakan alternatif seperti tepung ampas tahu dan kulit telur untuk mensubstitusi sebagian penggunaan ransum komersil broiler.

Secara umum, ayam-ayam kamaras dari semua perlakuan memperlihatkan masih terjadinya kenaikan berat badan (BB) sampai umur 10 minggu. Akan tetapi, rata-rata pertambahan berat badannya (PBB) per minggu selama rentang waktu 8, 9, dan 10 minggu relatif konstan, bahkan cenderung berkurang (Tabel 2). Ayam-ayam yang diberi seratus persen ransum komersil mengalami pengurangan rataan PBB selama rentang waktu delapan minggu atau lebih. Sedangkan, ayam-ayam dari perlakuan penambahan tepung ampas tahu + tepung kulit telur + feed supplement, pengurangan rataan PBB per minggu terjadi selama rentang waktu sembilan minggu atau lebih. Ini berarti penambahan tepung ampas tahu + tepung kulit telur + feed supplement dapat memperlambat pengurangan rataan $\mathrm{PBB}$ per minggu ayam kamaras. 


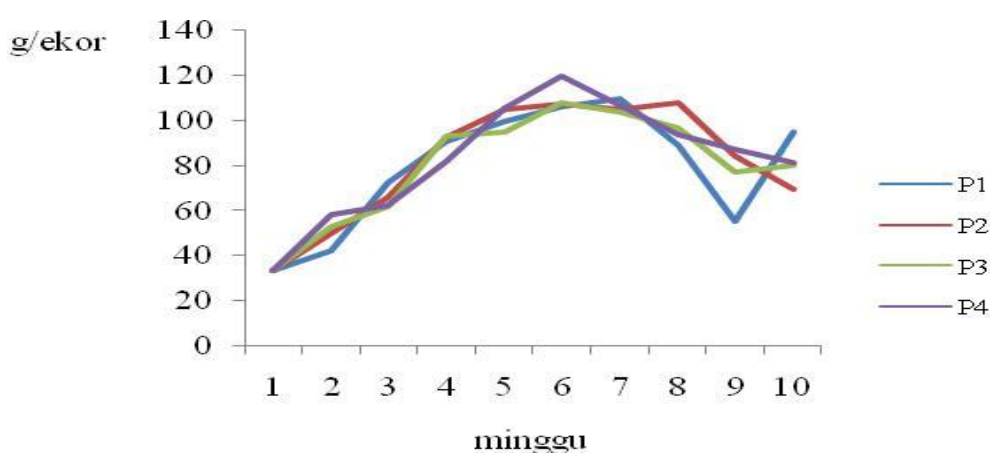

Gambar 2. Pertambahan Berat Badan Ayam Kamaras Tiap-Tiap Minggu dari Semua Perlakuan

Pertambahan berat badan ayam kamaras tiap-tiap minggu sejak dari DOC diperlihatkan pada Gambar 2. Dari data terlihat bahwa pola pertumbuhan ayam kamaras berbentuk sigmoid seperti halnya unggas-unggas lainnya (broiler, kalasan, dsb.). Pertumbuhan ayam kamaras terus meningkat sampai mencapai puncaknya, rata-rata terjadi pada minggu ke-6 pada ayamayam yang mendapatkan ransum komersil dengan substitusi tepung ampas tahu + tepung kulit telur + feed supplement , kemudian mulai menurun kembali. Sedangkan pada ayam-ayam yang mendapatkan seratus persen ransum komersil, puncak pertumbuhan terjadi pada minggu ke-7. Ini berarti penggunaan tepung ampas tahu + tepung kulit telur + feed supplement dapat mempersingkat masa pemeliharaan ayam kamaras.

\section{Total Konsumsi dan Rataan Konsumsi Ransum}

Total konsumsi ransum ayam kamaras dalam penelitian ini dihitung berdasarkan banyaknya ransum yang dihabiskan selama pemeliharaan 8, 9, dan 10 minggu. Rataan konsumsi ransum per minggu dihitung berdasarkan rata-rata konsumsi ransum yang dihabiskan dalam satu minggu selama pemeliharaan 8, 9, dan 10 minggu. Total konsumsi ransum dan rataan konsumsi ransum per minggu ayam kamaras dengan pemberian ransum komersil broiler 512 Bravo yang disubstitusi dengan tepung ampas tahu + tepung kulit telur + feed supplement selama pemeliharaan 8, 9, dan 10 minggu diperlihatkan pada Tabel 3.

Tabel 3. Total Konsumsi Ransum dan Rataan Konsumsi Ransum per minggu Ayam Kamaras yang diberi Ransum Komersil yang Disubstitusi dengan Tepung Ampas Tahu + Tepung Kulit Telur + Feed Supplement

\begin{tabular}{|c|c|c|c|c|}
\hline \multirow{2}{*}{$\begin{array}{c}\text { Parameter } \\
\text { (minggu) }\end{array}$} & \multicolumn{4}{|c|}{ Perlakuan } \\
\hline & P1 & $\mathrm{P} 2$ & P3 & $\mathrm{P} 4$ \\
\hline \multicolumn{5}{|c|}{ Total konsumsi ransum (total feed intake) (g/ekor) } \\
\hline $0-8 \quad$ minggu & $2066,27 \pm 61,65$ & $2069,21 \pm 28,26$ & $2037,19 \pm 105,79$ & $2078,77 \pm 87,47$ \\
\hline minggu & $2499,77 \pm 93,53$ & $2580,52 \pm 47,71$ & $2496,50 \pm 113,37$ & $2561,90 \pm 104,67$ \\
\hline $0-10$ minggu & $2981,25 \pm 122,44$ & $3072,40 \pm 46,42$ & $3089,57 \pm 140,47$ & $3076,15 \pm 102,26$ \\
\hline \multicolumn{5}{|c|}{ Rataan konsumsi ransum per minggu (average feed consumption) (g/ekor/minggu) } \\
\hline $0-8 \quad$ minggu & $258,28 \pm 7,71$ & $258,65 \pm 3,53$ & $254,65 \pm 13,22$ & $259,85 \pm 10,94$ \\
\hline minggu & $277,75 \pm 10,39$ & $286,73 \pm 5,30$ & $277,39 \pm 12,60$ & $284,65 \pm 11,63$ \\
\hline minggu & $298,13 \pm 12,24$ & $307,24 \pm 4,64$ & $308,96 \pm 14,05$ & $307,62 \pm 10,23$ \\
\hline & & & & \\
\hline$=$ Ransum Komersi & & & Feed Supplement 1 & \\
\hline
\end{tabular}


$\mathrm{P}_{4}=$ Ransum Komersil R512 81\% + Tepunga Ampas Tahu 15\% + Tepung Kulit Telur 3\% + Feed Supplement 1\%

Kenaikan berat badan ayam-ayam kamaras yang mendapatkan ransum yang mengandung tepung ampas tahu + tepung kulit telur + feed supplement bisa disebabkan faktor kenaikan konsumsi ransumnya. Meskipun hasil sidik ragam tidak ada perbedaan yang nyata $(\mathrm{P}>0,05)$ dalam rataan konsumsi ransum per minggu, ayam-ayam yang mendapatkan ransum yang mengandung tepung ampas tahu + tepung kulit telur + feed supplement memiliki rataan konsumsi ransum lebih tinggi dibandingkan dengan ayam yang mendapatkan ransum kontrol $\left(\mathrm{P}_{1}\right)$. Hal ini menunjukkan bahwa penggunaan tepung ampas tahu + tepung kulit telur + feed supplement meningkatkan nafsu makan ayam. Menurut Anggorodi (1985), semakin banyak bahan pakan yang digunakan semakin palatabel ransum.

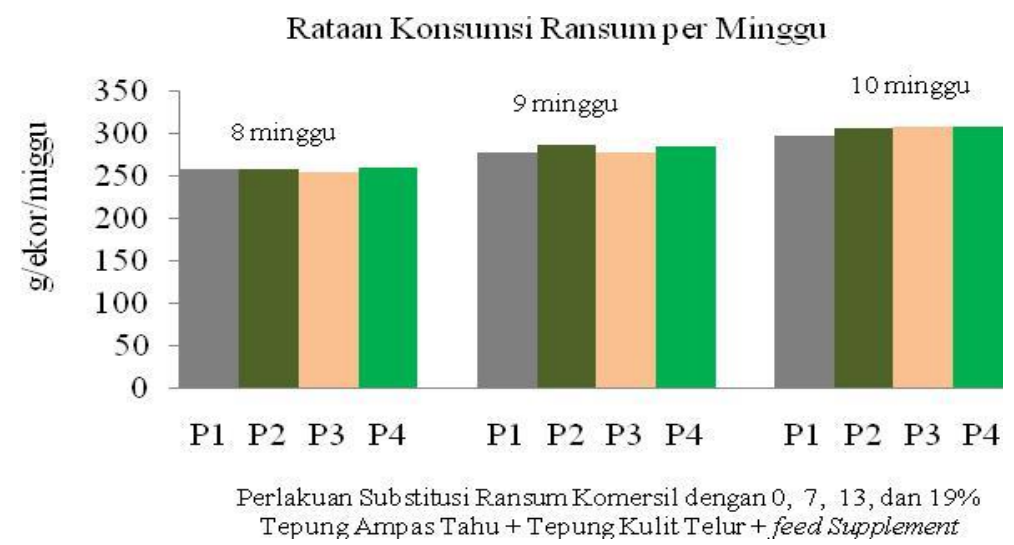

Gambar 3. Rataan Konsumsi Ransum per Minggu Ayam Kamaras dari Semua Perlakuan pada Selama 8, 9, dan 10 Minggu

Hasil ini menunjukkan bahwa tepung ampas tahu + tepung kulit telur + feed supplement dapat digunakan dalam pemeliharaan ayam kamaras sampai umur 10 minggu tanpa menunjukkan penurunan rataan konsumsi ransum. Selain itu, respon terhadap berat badan masih lebih baik sampai pemeliharaan sepuluh minggu. Jelas terlihat bahwa tepung ampas tahu + tepung kulit telur + feed supplement memberikan efek positif terhadap rataan konsumsi ransum dan berat badan ayam kamaras.

Konsumsi ransum ayam kamaras tiap-tiap minggu diperlihatkan pada Gambar 4, sedangkan datanya tertera pada. Dari grafik dapat dilihat bahwa rataan konsumsi ransum ayam kamaras dari semua perlakuan semakin meningkat dengan semakin bertambahnya umur. Sampai minggu ke-10 terlihat konsumsi ransum ayam kamaras masih terus bertambah. Hal ini dikarenakan berat badan ayam bertambah sehingga juga membutuhkan tambahan ransum. Sesuai dengan Fadilah (2004), konsumsi ransum setiap minggu bertambah sesuai dengan pertambahan bobot badan. 


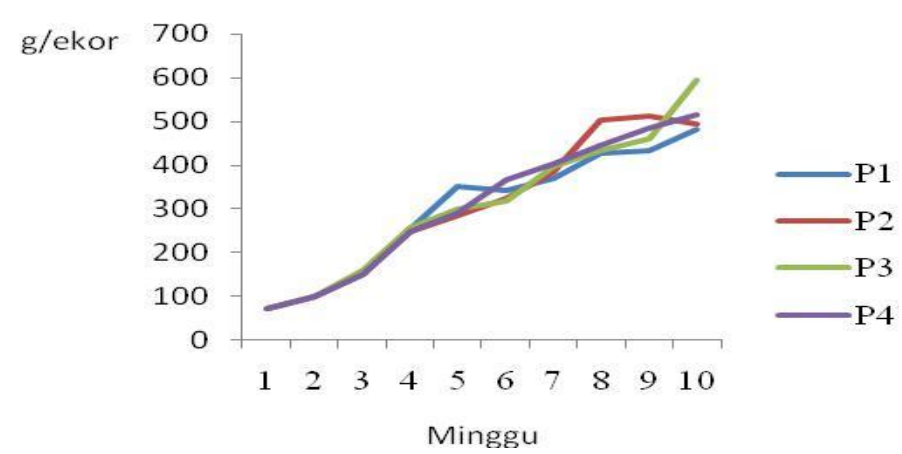

Gambar 4. Konsumsi Ransum Ayam Kamaras Tiap-

Tiap Minggu dari Semua Perlakuan

\section{Konversi dan Efisiensi Ransum}

Total konversi dan efisiensi ransum ayam kamaras dalam penelitian ini dihitung berdasarkan banyaknya ransum yang dihabiskan selama pemeliharaan 8, 9, dan 10 minggu dibandingkan dengan rataan pertambahan berat badan ayam selama pemeliharaan jangka waktu tersebut. Konversi dan efisiensi ransum ayam kamaras dengan pemberian ransum komersil broiler 512 Bravo yang disubstitusi dengan tepung ampas tahu + tepung kulit telur + feed supplement selama pemeliharaan 8, 9, dan 10 minggu diperlihatkan pada Tabel 4.

Tabel 4. Konversi dan Efisiensi Ransum Ayam Kamaras yang diberi Ransum Komersil yang Disubstitusi dengan Tepung Ampas Tahu + Tepung Kulit Telur + Feed Supplement

\begin{tabular}{|c|c|c|c|c|}
\hline \multirow{2}{*}{$\begin{array}{c}\text { Parameter } \\
\text { (minggu) }\end{array}$} & \multicolumn{4}{|c|}{ Perlakuan } \\
\hline & P1 & P2 & P3 & P4 \\
\hline \multicolumn{5}{|c|}{ Rataan konversi ransum per minggu (average feed convertion ratio) (g konsumsi ransum/g pbb) } \\
\hline 0-8 minggu & $3,22 \pm 0,20$ & $3,11 \pm 0,18$ & $3,20 \pm 0,40$ & $3,16 \pm 0,20$ \\
\hline minggu & $3,59 \pm 0,27$ & $3,45 \pm 0,24$ & $3,50 \pm 0,42$ & $3,44 \pm 0,26$ \\
\hline $0-10$ minggu & $3,76 \pm 0,26$ & $3,76 \pm 0,26$ & $3,90 \pm 0,55$ & $3,73 \pm 0,30$ \\
\hline \multicolumn{5}{|c|}{ Rataan efisiensi ransum per minggu (average feed eficiency ratio) (g pbb/g konsumsi ransum) } \\
\hline 0-8 minggu & $0,31 \pm 0,02$ & $0,32 \pm 0,02$ & $0,32 \pm 0,04$ & $0,32 \pm 0,02$ \\
\hline 0-9 minggu & $0,28 \pm 0,02$ & $0,29 \pm 0,02$ & $0,29 \pm 0,04$ & $0,29 \pm 0,02$ \\
\hline $0-10$ minggu & $0,27 \pm 0,02$ & $0,27 \pm 0,02$ & $0,26 \pm 0,04$ & $0,27 \pm 0,02$ \\
\hline
\end{tabular}

$\mathrm{P}_{1}=$ Ransum Komersil R512 100\% (kontrol)

$\mathrm{P}_{2}=$ Ransum Komersil R512 93\% + Tepung Ampas Tahu 5\% + Tepung Kulit Telur 1\% + Feed Supplement $1 \%$

$\mathrm{P}_{3}=$ Ransum Komersil R512 87\% + Tepung Ampas Tahu 10\% + Tepung Kulit Telur 2\% + Feed Supplement $1 \%$

$\mathrm{P}_{4}=$ Ransum Komersil R512 81\% + Tepunga Ampas Tahu 15\% + Tepung Kulit Telur 3\% + Feed Supplement $1 \%$

Hasil sidik ragam memperlihatkan bahwa pemberian ransum komersil broiler 512 Bravo yang disubstitusi dengan tepung ampas tahu + tepung kulit telur + feed supplement tidak berpengaruh nyata $(\mathrm{P}>0.05)$ terhadap konversi ransum ayam kamaras $(8,9$, dan 10 minggu). Meskipun demikian, ada kecenderungan ayam-ayam yang diberi ransum yang mengandung tepung ampas tahu + tepung kulit telur + feed supplement $\left(\mathrm{P}_{2}-\mathrm{P}_{4}\right)$ memiliki angka konversi ransum yang lebih baik dibandingkan dengan ayam yang mendapatkan ransum komersil seratus persen $\left(\mathrm{P}_{1}\right)$, yang diperlihatkan dengan angka konversi yang lebih kecil. Semakin kecil angka konversi ransum, semakin efisien penggunaan ransum (Rasyaf, 1994).

Hasil ini memperlihatkan bahwa tepung ampas tahu + tepung kulit telur + feed supplement dapat memperbaiki konversi ransum ayam kamaras. Zat-zat gizi yang terkandung di dalam tepung ampas tahu, tepung kulit telur, dan feed supplement dapat dimanfaatkan secara efisien oleh ayam kamaras. Adanya kenaikan konsumsi ransum sebagai akibat dari 
penggunaan tepung ampas tahu + tepung kulit telur + feed supplement tidak menjadi masalah karena kenaikan berat badan per satuannya masih lebih tinggi.

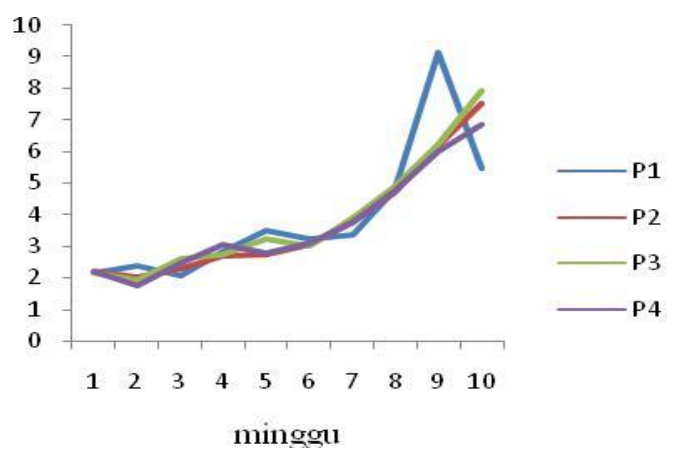

Gambar 5. Konversi Ransum Ayam Kamaras Tiap-Tiap Minggu dari Semua Perlakuan

Dari grafik dapat dilihat bahwa rataan konversi ransum ayam kamaras dari semua perlakuan semakin meningkat dengan semakin bertambahnya umur. Hal ini dikarenakan terjadinya kenaikan berat badan ayam semakin mengecil, sedangkan kenaikan konsumsi ransumnya semakin membesar. Seperti yang dikatakan oleh Wahyu (1992), salah satu faktor yang mempengaruhi konsumsi ransum adalah umur ayam, semakin bertambah umur semakin bertambah konsumsi ransumnya. Sedangkan menurut Anggorodi (1985), umur juga sebagai salah satu faktor yang berpengaruh dalam konversi ransum, semakin bertambah umur semakin besar angka konversi ransum. Namun demikian, kenaikan konversi ransum pada ayam-ayam kamaras yang mendapatkan ransum komersil dengan substitusi tepung ampas tahu+ tepung kulit telur + feed supplement lebih lambat daripada ayam yang mendapatkan seratus persen ransum komersil. Ini menunjukkan bahwa penggunaan tepung ampas tahu + tepung kulit telur + feed supplement dapat memperlambat kenaikan konversi ransum ayam kamaras, yang berarti lebih baik.

\section{Mortalitas}

Selama penelitian hanya satu ekor ayam yang mati dari 64 ekor $(1,6 \%)$, yaitu pada perlakuan $\mathrm{P}_{4}$ (ransum komersil R512 81\% + tepung ampas ahu 15\% + tepung kulit telur $3 \%+$ feed supplement $1 \%$ ). Namun, kematian ini bukan dikarenakan pengaruh perlakuan tetapi faktor individu ayam yang fisiknya lemah. Sebagian besar, ayam kamaras menunjukkan fisik yang kuat, kecuali satu ekor yang mati tersebut. Hal ini diduga karena adanya hasil persilangan dari ayam kampung yang lebih tahan terhadap stres dan penyakit. Menurut Sarwono (1991), salah satu kelebihan ayam kampung adalah tahan terhadap penyakit. Berdasarkan hasil penelitian ini dapat dikatakan ayam kamaras memiliki tingkat mortalitas yang rendah.

\section{KESIMPULAN DAN SARAN}

\section{Kesimpulan}

Penggunaan tepung ampas tahu + tepung kulit telur + feed supplement dapat digunakan untuk mensubstitusi penggunaan ransum komersil broiler 512 Bravo sampai 19\% tanpa berpengaruh nyata terhadap berat badan akhir, pertambahan berat badan, konsumsi, dan konversi ransum ayam kamaras. Meskipun secara statistik tidak nyata, penggunaan tepung ampas tahu + tepung kulit telur + feed supplement cenderung meningkatkan berat badan dan 
pertambahan berat badan, menaikkan konsumsi ransum, dan memperbaiki angka konversi ransum ayam kamaras.

\section{Saran}

Bagi peternak yang mengusahakan ayam kamaras sebaiknya mensubstitusi ransum komersil broiler 512 Bravo dengan tepung ampas tahu + tepung kulit telur dengan penambahan feed supplement. Perlu dilakukan penelitian lanjut tentang penggunaan bahanbahan pakan alternatif lainnya sebagai substitusi ransum komersil dalam pemeliharaan unggas khususnya ayam kamaras.

\section{DAFTAR PUSTAKA}

Anggorodi, R. 1985. Kemajuan Mutakhir dalam Ilmu Makanan Ternak Unggas. PT. Gramedia, Jakarta.

Butcher, G. D. and R. Miles. 1990. Concepts of Eggshell Quality. [Online]. (http://edis.ifas.ufl.edu/pdffiles/VM/VM01300.PDF 1990.

Fadilah, R. 2004. Ayam Broiler Komersial. Agromedia Pustaka, Jakarta.

Masturi, A. Lestari, dan R. Sukadarwati. 1992. Penelitian Pemanfaatan Limbah Padat Industri Tahu Untuk Pembuatan Isolasi Protein. Balai Penelitian dan Pengembangan Industri. Departemen Perindustrian, Semarang, Laporan Penelitian (Tidak Dipublikasikan).

Natalia, H., D. Nista, Sunarto, dan D. S. Yuni. 2005. Pengembangan Ayam Arab. Balai Pembibitan Ternak Unggul Sembawa. Balai Pembibitan Ternak Unggul (BPTU) Sapi Dwiguna dan Ayam Sembawa, Palembang.

Nur, S.Y., D. Ade, dan F. L. Yose. 1997. Penggunaan biokonversi ampas tahu dengan laru tempe dalam ransum broiler. Pros. Seminar Nasional II Ilmu Nutrisi dan Makanan Ternak. Fakultas Peternakan, Institut Pertanian Bogor. Bogor: 113-114.

Pambudhi, W. 2003. Mengenal Ayam Arab Merah. Cet. ke-1. Agromedia Pustaka, Jakarta. Prabowo, A., D. Sarnaih, dan M. Rangkuti. 1983. Pemanfaatan ampas tahu sebagai makanan tambahan dalam usaha penggemukan domba potong. Prosiding Seminar Pemanfaatan Limbah Pangan dan Limbah Pertanian Untuk Makanan Ternak. LIPL, Bandung.

Pulungan, H. dan M. Rangkuti. 1984. Ampas Tahu Untuk Makanan Ternak. Warta Penelitian dan Pengembangan Pertanian. Departemen Pertanian Bogor: 331-335.

Rasyaf, M. 1994. Beternak Ayam Pedaging. Penebar Swadaya, Jakarta.

Sarwono, B. 1991. Beternak Ayam Buras. Cet. ke-3. Penebar Swadaya, Jakarta.

Steel, R. G. D. dan J. H. Torrie, 1993. Prinsip dan Prosedur Statistika. Terjemahan oleh B. Sumanti. Cet. ke-2. PT. Gramedia, Jakarta.

Sulandari, S., A. Zein, S. Paryanti, T. Sartika, M. Astuti, T. Widjastuti, E. Sudjana, S. Darana, I. Setiawan, dan D. Garnida. 2007. Sumber daya genetik ayam lokal Indonesia. Keanekaragaman Sumber Daya Hayati Ayam Lokal Indonesia: Manfaat dan Potensi. Pusat Penelitian Biologi, Lembaga IImu Pengetahuan Indonesia, Bogor.

Triharyanto, B. 2001. Peternakan Ayam Arab. Kanisius, Yogyakarta.

Wahyu, J. 1992. Ilmu Nutrisi Unggas. Cet. ke-3. Gadjah Mada University Press. Yogyakarta.

Yaman, M.A., Yurliasni, dan Zulfan. 2011. Peningkatan Potensi Genetik Ayam Lokal Melalui Kombinasi Metode Seleksi dengan Analisa Protein, RNA, dan M-RNA, Aplikasi Kawin Silang (croosbreeding) Serta Penyesuai Nutrisi Untuk Mendapatkan Kandidat Pejantan Ayam Petelur Unggul. Laporan Penelitian Insentif Riset Terapan Kemenristek. 


\section{UCAPAN TERIMAKASIH}

Penulis menyampaikan terima kasih yang sebesar-besarnya kepada Murniati dan Uswatun Hasanah atas kerjasamanya yang baik selama penelitian serta semua pihak yang turut membantu dalam penelitian ini. 